\title{
The Effectiveness of Quarantine Interventions on the Spread of Corona Virus 2019: A Systematic Review
}

\author{
Cecep Eli Kosasih ${ }^{1 *}$ (D) Tetti Solehati ${ }^{2}$, Yanny Trisyani ${ }^{1}$ (D) \\ ${ }^{1}$ Department of Emergency and Critical Care Nursing, Faculty of Nursing, Universitas Padjadjaran, Sumedang, West Java, \\ Indonesia; ${ }^{2}$ Department of Maternity Nursing, Faculty of Nursing, Universitas Padjadjaran, Sumedang, West Java, Indonesia
}

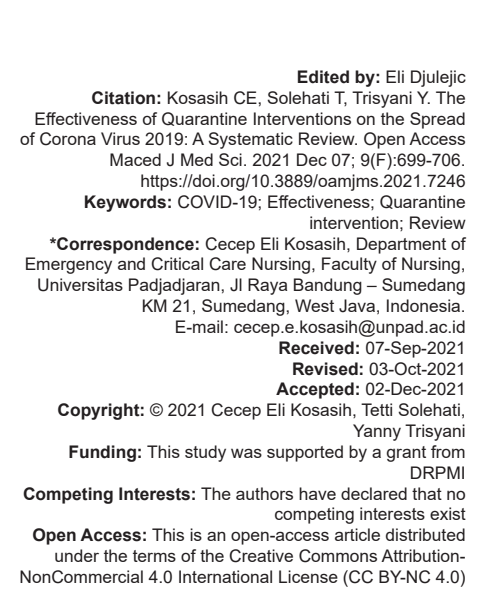

Introduction

The world is currently busy facing COVID-19 disease pandemic [1]. This virus is a terrible thing, it spreads very quickly throughout the world and the number of cases is increasing sharply [2]. This shows that this disease is a serious threat to health globally [3], [4]. So that the World Health Organization (WHO), in March 2020, declared that this situation was categorized as a pandemic [5], [6] and became an international public health emergency in January 2020 [7].

The novel coronavirus pneumonia was first identified in the Chinese city of Wuhan, referred to as Coronavirus disease 19 (COVID-19) by the WHO [8]. In December 2019, in Wuhan City, Hubei Province, China, became the center of an outbreak of pneumonia with no known cause, where this outbreak caused great attention both in China and internationally [9], [10]. This virus initially spread rapidly throughout China [11]. So the Chinese health authorities then carried out an immediate investigation to characterize and control the disease, including the isolation of people suspected of having the disease [12].

\begin{abstract}
CKGROUND: The COVID-19 virus has become a terrible thing and is a serious threat to health globally which due to the Coronavirus 2019 (COVID-19).

METHODS: Searching for articles was using electronic databases in English such as CINAHL (EBSCO), Science 2019 and 2020 .

RESULTS: Seven quarantine intervention programs were demonstrated to prevent and reduce the spread of intervention, (3) quarantine programs based on laboratories, and (4) quarantine programs on cruise ships.

CLNCION: Successful interventions were characterized by a combination of multi-sectorial collaboration, This program has proven to be beneficial in preventing or reducing the spread of COVID-19. Suggestion: The government can use these programs to prevent and reduce the spread of disease caused by COVID-19.
\end{abstract}

The COVID-19 cases are no longer limited to Wuhan alone but have spread to Hong Kong, Macau, and Taiwan [13]. In January 2020, the disease had spread to Thailand, Japan, Korea, the United States, Vietnam, and Singapore [5], [13], [14], [15]. Then in March 2020, the spread of COVID-19 began to seem uncontrollable, where only in the past week, the outbreak has emerged in all countries such as Iran, Iraq, Oman, Bahrain, Italy, Austria, and Croatia, and Japan. Italy is the ten cities where the virus is spreading rapidly [16].

The COVID-19 virus is suspected by experts to have spread secretly to many places. A modeling group at Imperial College London estimates that it is likely that about two-thirds of cases transmitted from China have not been detected [16]. There are concerns that the 2019-nCoV-induced outbreak could spread globally with the continuous transmission in countries around the world [17], [18], [19], [20].

The COVID-19 virus was identified by the International Committee on Taxonomy of Viruses (ICTV) as "severe acute respiratory syndrome coronavirus 2" (SARS-CoV-2), and a report from the ICTV Coronaviridae Study on February 11, 2020. The pneumonia outbreak became a global concern when The Wuhan Municipal Health Commission reported on December 31, 2019, 
there were 27 cases of viral pneumonia, including seven critical cases [8]. As of February 14, 2020, there were a total of 48,548 laboratory-confirmed cases (1998 new) and 1381 deaths (121 new) reported in China, as well as 505 laboratory-confirmed cases (58 new) and two deaths (1 new) in 24 countries outside China [5].

The virus outbreak is spreading rapidly, reaching a total of more than 50,000 cases and 1000 deaths reported in China as well as 603 cases worldwide, [5], [21] this figure has surpassed the 2003 outbreak of SARS [22]. Then on April 6, 2020, the virus quickly spread to most countries around the world, affecting more than 1.1 million people, and causing nearly 63,000 deaths [5].

This virus is most similar to the SARS, [23] which in 2002-2003 was a major case in 37 countries [23], [24]. Common symptoms at the start of a disease with COVID-19 are fever, cough, and myalgia or fatigue. Meanwhile, less common symptoms include sputum production, headache, hemoptysis, and diarrhea [25]. The progression of the disease to acute respiratory distress syndrome occurred about 8-12 days after the onset of symptoms, and the greatest severity occurred about 10 days after the team [26] had the initial symptoms [4], [18], [27].

The WHO reported that the new coronavirus (2019-nCoV) was identified as the causative virus by the Chinese authorities on January 7, 2020. The risk factors for COVID-19 are estimated to be mainly transmitted through droplets from infected people [28], by air, shakes hands, skin touch, hugs, and being close to people with COVID-19. The risk factors for those who are prone to contracting COVID-19 are older age [25], children and infants [29], male sex, have a history of previous diseases such as diabetes mellitus, hypertension, and cardiovascular disease [18]. The COVID-19 case causes a high mortality rate [18] because it is easily transmissible, and causes many physical and mental [7], social, spiritual, and economic losses. For health workers, COVID-19 has created psychological distress and challenges [29], where many feels exhausted as a result of caring for more and more patients at the expense of their own wellbeing and become infected. In society, there is anxiety and depression due to fear of infection, excessive media information, and panic buying necessities [30]. Economic actors have caused economic losses which led to mass layoffs.

The nature of the virus which is easily transmitted causes people to be suspicious and shut themselves off from the social environment. In addition, houses of worship were closed because it is thought to be a gathering area for many people who are at high risk of infection due to the proximity to one another where there is a possibility that there are positive sufferers of COVID-19 who are not aware of it.

Various countries have tried to make efforts to address the problems caused by COVID-19. To control the epidemic of this virus, the Chinese government on January 23, 2020, ordered the quarantine of the city of Wuhan, implementing an unprecedented intervention strategy [8], [21]. These policies include large-scale quarantine, strict control of travel, and extensive monitoring of suspected cases [21]. All cities in China are under quarantine including national school closures as an emergency measure to prevent the spread of infection, extended national holidays, restricting public activities, taking strict measures to restrict travel and public gatherings, closed public spaces, and strict temperature monitoring [21], [31].

Almost all countries have implemented quarantine policies to prevent the spread of COVID-19 by implementing mitigation measures, such as traffic restrictions, cancellation of social gatherings, and home quarantine [6]. Quarantine is associated with reduced transmission rates. Centralized patient quarantine and contacts appear to have been associated with reduced transmission in hospitals, households, and communities [6]. During this time, the international community has paid great attention to the effectiveness of quarantine [32]. Quarantine is expected to minimize transmission of COVID-19. The key factor in slowing transmission of the virus is "social distancing" by reducing human-to-human contact [2]. It should be emphasized that the importance of current surveillance efforts in countries around the world is done to ensure that the ongoing outbreak will not become a global pandemic [20].

Governments in various countries have started to carry out quarantine interventions both independently and in combination to prevent outbreaks, although it is not known whether community interventions can improve the control of the COVID-19 outbreak [6], and no studies have been found regarding its effectiveness quarantine against the spread of COVID-19. Therefore, it is necessary to carry out literature research to investigate quarantine interventions that are effective in reducing the spread of COVID-19 cases.

This research aimed to: (1) Investigate quarantine interventions that are effective in reducing the spread of COVID-19 carried out in the world between December 2019 and April 2020, and (2) analyzing the potential impact of the regulation of the COVID-19 outbreak in the world.

This research is useful to assist policymakers in making efforts to prevent and control the spread of disease due to COVID-19, as well as to collect and critically analyze the distribution of quarantine intervention programs in all countries affected by COVID-19.

\section{Methods}

In this systematic review, the researcher uses the guidelines from the Preferred Reporting Items for 
Systematic Reviews and Meta-Analyzes [33] in this systematic review.

\section{Study selection and eligibility}

The inclusion criteria in these studies were as follows: (1) Published in peer-reviewed scientific journals; (2) focus on quarantine interventions to prevent the spread of COVID-19; (3) published between December 2019 and April 2020; (4) articles in English; (5) full text; (6) RCT, Quasi experiment, cohort study; and (7) involving human subjects (Table 1).

\section{Data search strategy}

Authors include RCT studies, quasiexperiments, and cohort studies examining quarantine interventions related to COVID-19. Sourcing through electronic literature databases (PubMed, Medline-EBSCO, ProQuest, Science Direct, CINAHL-EBSCO, Academic Search Complete-EBSCO, Springer Link, Sage Journal, Cambridge Core, Taylor and Francis Online, Clinical key, Willey Online Library, and Scopus) to search for articles related to quarantine interventions related to COVID-19 in 2019-2020. Search was carried out using medical subject headings and keyword such as intervention, COVID-19, coronavirus, quarantine using 13 databases using the same search strategy in 13 databases.

\section{Study selection and data collection}

Researchers identified and filtered abstracts of all English articles in the database. Quarantine data related to COVID-19 such as epidemiological reviews, conference proceedings, thesis reports, meta-analyzes, systematic reviews, comments, review literature, and editorial were not included in this study. Only studies related to COVID-19 quarantine in the form of RCTs, quasi-experiments, and cohort studies were included in this systematic review study. A total of 2210 studies were screened based on titles and abstracts, then released 1522 studies which were editorial research, commentary, literature review, thesis, conference proceedings, not related to quarantine-related interventions related to COVID-19, and not in English, leaving 688 articles. Furthermore, the researchers issued 661 studies because of duplication, were literature studies and were not quarantine interventions related to COVID-19 so that 27 studies had the potential to meet the requirements. Of the 27 articles, only six articles met the requirements. The study flow chart is presented in Figure 1. Representativeness, relevance, study design, clarity of objectives, and evidence of an ethical approach were considered among the quality criteria.

Framework: The population, intervention, comparators and outcomes (PICO) (Table 1).

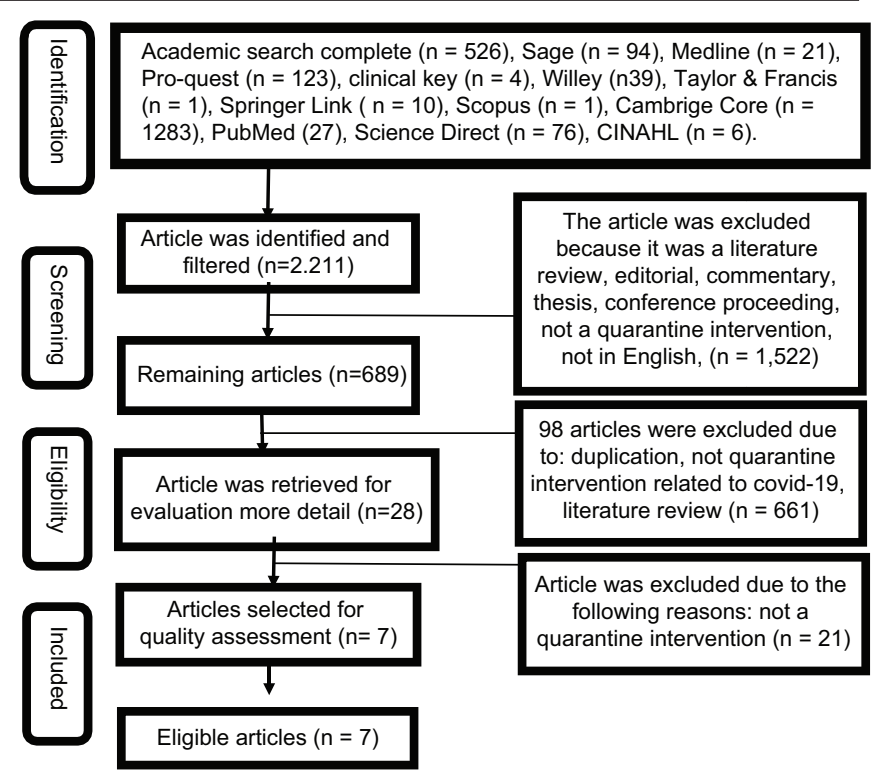

Figure 1. Summary of the research article selection process

After screening full-text articles and assessed for quality using a quality assessment tool, only six studies were identified as meeting the essential criteria. All articles identified as relevant to quarantine interventions related to COVID-19 by one of the authors were submitted for full text review and data extraction. The first and second authors reviewed all abstracts of the articles identified in the database. All data are obtained in electronic form. All four authors reviewed the full text of the screened articles for assessment and confirmed their eligibility. Each author filled out the study data extraction form for eligible articles. The article was selected to report results from the latest literature on quarantine related to COVID-19. The identified articles from the electronic database are transferred and stored in the EndNote software X5.01. A brief description of the selected studies is shown in Table 2. Every effort was made to reduce the risk of bias in this review by a panel of experts consisting of three academics who had been trained.

Table 1: Framework: The PICO

\begin{tabular}{llll}
\hline Population & Intervention & Comparison of & Outcomes \\
\hline Community & A quarantine program with various & Social distancing & Reduced \\
& methods related to the prevention of \\
the spread of COVID-19, both social & programs, & self-isolation, & incidence of \\
& distancing methods, self-isolation, \\
large-scale, and social restrictions. & large-scale social & restrictions. & to COVID-19. \\
\hline PICO: Population, intervention, comparators, and outcomes & &
\end{tabular}

\section{Data extraction}

Reviewers extracted data by one reviewer and checked by another. All studies that met the inclusion criteria were assessed according to the JBI Critical Appraisal Checklist for RCT and The Cochrane Collaboration's tool for assessing risk of bias in randomized trials including: 1) Authors; 2) year of publication; 3) research title; 4) geographic area of research; 5) research objectives 6) study design; 7) samples and sampling techniques; 8) data analysis; 
Table 2: Summarizing and reporting the results

\begin{tabular}{|c|c|c|c|c|c|c|c|}
\hline Name and year & Objectives & Method & Sampling & Analysis & Treatment & Results & Conclusion \\
\hline $\begin{array}{l}\text { (Hou et al., 2020) } \\
\text { Wuhan China }\end{array}$ & $\begin{array}{l}\text { To explore the } \\
\text { effectiveness of } \\
\text { the Wuhan city } \\
\text { quarantine against } \\
\text { this epidemic, } \\
\text { the dynamics } \\
\text { of COVID-19 } \\
\text { transmission }\end{array}$ & $\begin{array}{l}\text { Well-mixed the } \\
\text { "SEIR" combined } \\
\text { compartmental } \\
\text { model }\end{array}$ & $\begin{array}{l}\text { Vulnerable } \\
\text { populations, exposed } \\
\text { populations, } \\
\text { symptomatic } \\
\text { infected populations, } \\
\text { and recovered } \\
\text { populations. }\end{array}$ & $\begin{array}{l}\text { Software } \\
\mathrm{R} \text { (version 3.6.1) }\end{array}$ & $\begin{array}{l}\text { Referring to SARS } \\
\text { epidemic data, the level } \\
\text { of contact of infected } \\
\text { individuals after quarantine } \\
\text { and isolation is regulated. }\end{array}$ & $\begin{array}{l}\text { The mixed SEIR } \\
\text { model matched the } \\
\text { results based on the } \\
\text { assumption of latent } \\
\text { individual contact } \\
\text { rates to be within } \\
6-18 \text {, representing } \\
\text { the possible impact } \\
\text { of quarantine and } \\
\text { isolation interventions } \\
\text { on infectious disease, } \\
\text { whereas other } \\
\text { parameters were } \\
\text { considered unchanged. }\end{array}$ & $\begin{array}{l}\text { By reducing the level } \\
\text { of latent individual } \\
\text { contact, interventions } \\
\text { such as quarantine } \\
\text { and isolation could } \\
\text { effectively reduce the } \\
\text { potential peak number } \\
\text { of COVID-19 AND } \\
\text { infections delay the } \\
\text { peak infection time. }\end{array}$ \\
\hline $\begin{array}{l}\text { (Koo et al., 2020) } \\
\text { Singapore }\end{array}$ & $\begin{array}{l}\text { To investigate } \\
\text { early intervention } \\
\text { in Singapore if the } \\
\text { local detention (for } \\
\text { example, prevent the } \\
\text { spread of disease } \\
\text { through tracing } \\
\text { contact effort) is not } \\
\text { work. }\end{array}$ & $\begin{array}{l}\text { Influenza epidemic } \\
\text { simulation mode } \\
\text { of SARS-CoV-2 } \\
\text { infection } \\
\text { parameters }\end{array}$ & $\begin{array}{l}\text { School community, } \\
\text { home community, } \\
\text { and work place } \\
\text { Respondents are } \\
\text { divided into 2: } \\
\text { Intervention and } \\
\text { control (baseline) } \\
\text { group }\end{array}$ & $\begin{array}{l}\text { Statistical } \\
\text { software } \\
\mathrm{R} \text { (version 3.6.3) } \\
\text { for plotting } \\
\text { graphs and for all } \\
\text { analyzes }\end{array}$ & $\begin{array}{l}\text { In the intervention group } \\
\text { there were four intervention } \\
\text { scenarios: } \\
\text { (1) Group quarantine: } \\
\text { isolation of infected } \\
\text { individuals and } \\
\text { quarantine of their } \\
\text { family members. } \\
\text { (2) Quarantine } \\
\text { plus (school): Direct } \\
\text { school closure for } \\
2 \text { weeks of quarantine } \\
\text { plus (workplace } \\
\text { distancing): } 50 \% \text { of } \\
\text { the workforce are } \\
\text { encouraged to work } \\
\text { from home for } 2 \text { weeks; } \\
\text { (3) Combined intervention: } \\
\text { immediate school } \\
\text { closure, and workplace } \\
\text { distancing. } \\
\text { (4) In the baseline } \\
\text { group: none of the } \\
\text { interventions }\end{array}$ & $\begin{array}{l}\text { The results of the } \\
\text { study prove that } \\
\text { in the intervention } \\
\text { group there was a } \\
\text { decrease in COVID } \\
\text { cases compared to } \\
\text { the baseline group. } \\
\text { Compared with the } \\
\text { baseline scenario, } \\
\text { intervention the } \\
\text { combine dis were most } \\
\text { effective }\end{array}$ & $\begin{array}{l}\text { Intervention } \\
\text { combinations (combine } \\
\text { quarantines, school } \\
\text { closures, and } \\
\text { workplace distancing) } \\
\text { to prevent national } \\
\text { epidemic at the level } \\
\text { of for low infectivity } \\
\text { and significantly } \\
\text { reduced total number } \\
\text { of infections at higher } \\
\text { rates of infectivity. }\end{array}$ \\
\hline $\begin{array}{l}\text { (That et al., 2020) } \\
\text { China }\end{array}$ & $\begin{array}{l}\text { To demonstrate how } \\
\text { Al control measures, } \\
\text { impact epidemic } \\
\text { containment. }\end{array}$ & $\begin{array}{l}\text { Population } \\
\text { migration data } \\
\text { before and after } \\
\text { January } 23 \text { and } \\
\text { epidemiological } \\
\text { data for the most } \\
\text { updated COVID-19 } \\
\text { into the SEIR AI } \\
\text { approach }\end{array}$ & $\begin{array}{l}\text { Population into four } \\
\text { possible states: } \\
\text { Vulnerable [S], } \\
\text { Exposed or latent [E], } \\
\text { Infectious [l] or } \\
\text { Removed [R]. }\end{array}$ & & $\begin{array}{l}\text { Methods Data source } \\
\text { the most recent } \\
\text { epidemiological data } \\
\text { based on the daily } \\
\text { number of COVID-19 } \\
\text { outbreaks reported by the } \\
\text { Chinese National Health } \\
\text { Commission were taken. } \\
\text { Migration index based on } \\
\text { the daily number of events } \\
\text { in and out by rail, air and } \\
\text { traffic path, sourced from } \\
\text { a web-based program. } \\
\text { Epidemic data } \\
\text { SARS } 2003 \text { between April } \\
\text { and June } 2003 \text { across } \\
\text { China taken from an } \\
\text { archived news site (SOHU) } \\
\text { used for Al training }\end{array}$ & $\begin{array}{l}\text { It found that the } \\
\text { Chinese epidemic will } \\
\text { peak in late February, } \\
\text { indicating a gradual } \\
\text { decline in late April }\end{array}$ & $\begin{array}{l}\text { Dynamic SEIR } \\
\text { model is effective } \\
\text { in predicting the } \\
\text { peak and size of the } \\
\text { COVID-19 epidemic. } \\
\text { Implementation of } \\
\text { control measures on } \\
23 \text { January } 2020 \text { is } \\
\text { urgently needed to } \\
\text { reduce the size of the } \\
\text { COVID-19 epidemic }\end{array}$ \\
\hline $\begin{array}{l}\text { (Pan et al., 2020) } \\
\text { Wuhan China }\end{array}$ & $\begin{array}{l}\text { To evaluate the } \\
\text { relationship between } \\
\text { public health } \\
\text { interventions and } \\
\text { epidemiological } \\
\text { features of the } \\
\text { COVID-19 outbreak } \\
\text { in Wuhan. }\end{array}$ & Kohort study & $\begin{array}{l}32583 \text { confirmed } \\
\text { cases of COVID-19 } \\
\text { were reported } \\
\text { between December } \\
8,2019 \text { and March } 8 \text {, } \\
2020, \text { extracted from } \\
\text { the City's verifiable } \\
\text { Disease Report } \\
\text { System, including } \\
\text { patient age, sex, } \\
\text { location of residence, } \\
\text { occupation, and } \\
\text { severity classification. }\end{array}$ & $\begin{array}{l}\text { Regression } \\
\text { SAS statistical } \\
\text { software } \\
\text { version } 9.3\end{array}$ & $\begin{array}{l}\text { Exposure } \\
\text { Non-pharmaceutical } \\
\text { public health interventions } \\
\text { include cordon sanitation, } \\
\text { traffic restrictions, social } \\
\text { distancing, home isolation, } \\
\text { centralized quarantine, } \\
\text { and universal symptom } \\
\text { surveys. }\end{array}$ & $\begin{array}{l}\text { Results among } \\
32583 \text { cases of } \\
\text { COVID-19, the mean } \\
\text { age of patients was } \\
56.7 \text { years, more } \\
\text { women. The daily } \\
\text { case rate peaked in } \\
\text { the third period and } \\
\text { decreased thereafter } \\
\text { across Geographical } \\
\text { regions and for sex } \\
\text { and age groups, } \\
\text { except for children } \\
\text { and adolescents. } \\
\text { The rate of daily } \\
\text { cases throughout the } \\
\text { period among local } \\
\text { health care workers } \\
\text { was higher than the } \\
\text { general population. } \\
\text { The proportion of } \\
\text { severe and critical } \\
\text { cases decreased from } \\
53.1 \% \text { to } 10.3 \% \text { over } 5 \\
\text { periods. The risk of } \\
\text { severity increases } \\
\text { with age }\end{array}$ & $\begin{array}{l}\text { A diverse range } \\
\text { of public health } \\
\text { interventions have } \\
\text { been linked to } \\
\text { improved control of the } \\
\text { COVID-19 outbreak }\end{array}$ \\
\hline
\end{tabular}


Table 2: (Continued)

\begin{tabular}{|c|c|c|c|c|c|c|c|}
\hline Name and year & Objectives & Method & Sampling & Analysis & Treatment & Results & Conclusion \\
\hline $\begin{array}{l}\text { Lagie et al. 2020) } \\
\text { Prance }\end{array}$ & $\begin{array}{l}\text { To test expats for } \\
\text { SARS-CoV-2 twice } \\
\text { in order to reduce } \\
\text { and decision makers }\end{array}$ & $\begin{array}{l}\text { Researchers } \\
\text { investigated } \\
\text { the presence of } \\
\text { SARS-CoV-19 } \\
\text { by testing all } \\
\text { discharged patients } \\
\text { within the first } 24 \\
\text { h of their arrival } \\
\text { in France and on } \\
\text { day } 5 \text {. Viral RNA } \\
\text { was extracted } \\
\text { from nasal and } \\
\text { oropharyngeal } \\
\text { swab fluids or } \\
\text { sputum in the } \\
\text { absence of multiple } \\
\text { real time RT-PCR } \\
\text { tests. }\end{array}$ & $\begin{array}{l}\text { The total sample } \\
\text { of } 337 \text { consisted of } \\
170 \text { males }(50.4 \%) \text {, } \\
\text { mean age } \\
31 \text { years (range } \\
0-75 \text { years) }\end{array}$ & $\begin{array}{l}\text { Samples were } \\
\text { taken from } 3 \\
\text { flights } 178 \text { (first), } \\
124 \text { (second) and } \\
35 \text { (third) }\end{array}$ & $\begin{array}{l}\text { Researcher collected } \\
\text { one nasal and one } \\
\text { oropharyngeal swab } \\
\text { and one sputum sample } \\
\text { from each individual. For } \\
\text { children under the age } \\
\text { of three, a nasal rinse } \\
\text { was performed. A team } \\
\text { consisting of between } \\
\text { two and seven infectious } \\
\text { disease specialists was } \\
\text { sent to the two quarantine } \\
\text { bases to test asymptomatic } \\
\text { persons. }\end{array}$ & $\begin{array}{l}\text { Researcher tested } 337 \\
\text { passengers at day } 0 \\
\text { and day } 5 . \text { All the tests } \\
\text { for SARS-CoV2 were } \\
\text { negative }\end{array}$ & $\begin{array}{l}\text { The procedures reduce } \\
\text { anxiety and reassures } \\
\text { the population and } \\
\text { decision makers }\end{array}$ \\
\hline $\begin{array}{l}\text { Rocklöv } \\
\text { et al. (2020) } \\
\text { Sweden }\end{array}$ & $\begin{array}{l}\text { Estimating } \\
\text { the baseline } \\
\text { reproduction } \\
\text { numbers from the } \\
\text { initial outbreak } \\
\text { period using the } \\
\text { SEIR model }\end{array}$ & $\begin{array}{l}\text { Calibrate the } \\
\text { model with the } \\
\text { transient event } \\
\text { data response } \\
\text { function. Estimating } \\
\text { counterfactual } \\
\text { scenarios in } \\
\text { the absence of } \\
\text { countermeasures, } \\
\text { and establishing a } \\
\text { grouped model by } \\
\text { crew and guests } \\
\text { to study the impact } \\
\text { of differential } \\
\text { levels of contact } \\
\text { between groups. } \\
\text { Also compares } \\
\text { previous and later } \\
\text { ship evacuation } \\
\text { scenarios }\end{array}$ & $\begin{array}{l}\text { The population was } \\
\text { homogeneous ( } 3700 \\
\text { individuals), and } \\
\text { the population is } \\
\text { stratified crew (1000 } \\
\text { individuals) and } \\
\text { guests (2700 } \\
\text { individuals). }\end{array}$ & SEIR models & $\begin{array}{l}\text { Researchers used } 21 \\
\text { January } 2020 \text { as the } \\
\text { first point in time, } t=0 \text {, } \\
\text { COVID-19 related to cruise } \\
\text { ships derived using a } \\
\text { compartment model that } \\
\text { estimates the dynamics } \\
\text { of the number of people } \\
\text { who are susceptible (S), } \\
\text { exposed (E), infected } \\
\text { (I), and recovered (R), } \\
\text { adapted but modified from } \\
\text { a published COVID-19 } \\
\text { study }\end{array}$ & $\begin{array}{l}\text { The cumulative number } \\
\text { of cases modeled on } \\
\text { February } 19,2020 \text {, } \\
\text { was } 613 \text { out of } 3,700 \\
\text { people at risk, while the } \\
\text { number of observed } \\
\text { cases reported was } \\
619 .\end{array}$ & $\begin{array}{l}\text { The initial evacuation } \\
\text { of all passengers } \\
\text { on the cruise } \\
\text { ship - a situation } \\
\text { with limited space } \\
\text { and high mixing - is } \\
\text { recommended as } \\
\text { soon as the COVID-19 } \\
\text { outbreak is confirmed. }\end{array}$ \\
\hline $\begin{array}{l}\text { Telles et al. (2021) } \\
\text { Brazil }\end{array}$ & $\begin{array}{l}\text { To compare the } \\
\text { outcomes of policies } \\
\text { adopted by countries } \\
\text { between January } \\
\text { and April } 2020\end{array}$ & $\begin{array}{l}\text { Testing the } \\
\text { policies used } \\
\text { as a preventive } \\
\text { framework for } \\
\text { virus community } \\
\text { transmission in } \\
\text { some countries and } \\
\text { compared it to the } \\
\text { policies adopted } \\
\text { by China and } \\
\text { South Korea }\end{array}$ & $\begin{array}{l}\text { March } \\
28-30(n=56,337), \\
\text { April } \\
11-13(n=71,619), \\
\text { May } 1-2(n=60,807) \\
\text { consisted of } 29 \\
\text { countries }\end{array}$ & $\begin{array}{l}\text { Policies as } \\
\text { a preventive } \\
\text { framework }\end{array}$ & $\begin{array}{l}\text { The first group } \\
\text { implemented social } \\
\text { distancing }(1-2 \mathrm{~m}) \text { only, } \\
\text { and the second comprised } \\
\text { China and South Korea, } \\
\text { which implemented } \\
\text { distancing with additional } \\
\text { transmission/isolation } \\
\text { measures using masks and } \\
\text { city disinfection }\end{array}$ & $\begin{array}{l}\text { Virus transmission was } \\
\text { reduced due to policies } \\
\text { affecting SARS-CoV-2 } \\
\text { propagation over time }\end{array}$ & $\begin{array}{l}\text { Social distancing by } \\
1-2 \mathrm{~m} \text { with mask use } \\
\text { and city disinfection } \\
\text { yields positive } \\
\text { outcomes }\end{array}$ \\
\hline
\end{tabular}

9) explanation of the intervention; 10) Main findings, and 11) conclusions. A narrative synthesis of evidence was performed for all studies.

\section{Results}

\section{Study selection}

Initial search for articles combining all keywords from the electronic literature database yielded 2210 titles. After removing duplication, articles editorial, conference proceedings, systematic review theses, non-English articles, not focusing on quarantine interventions to prevent the spread of COVID-19, seven articles are left that are eligible (Figure 1).

\section{Study characteristics from eligible studies}

Based on the research results, there were six articles that examine the effectiveness of quarantine to prevent the spread of the COVID-19 virus. From these articles, five articles explained that the quarantine program was carried out and the next was calculated using the SEIRS application, one article was conducted with a cohort shortcut, policies analysis, and one more article using the COVID-19 signs check method. In addition, policies affecting SARS-CoV-2 propagation influenced to prevent the spreading virus transmission [34]. There were several quarantine programs carried out to prevent and reduce the spread of COVID-19 which were divided into four types of programs, namely:

\section{Quarantine program in China}

In this quarantine program carried out by the Chinese government then estimation and analysis are carried out using the SEIRS application. The effectiveness of the quarantine program in the city of Wuhan was analyzed by Hou et al. (2020) in Wuhan City, China which aims to explore the effectiveness of the Wuhan city quarantine against this epidemic; the dynamics of COVID-19 transmission have been 
estimated [8]. The results show that considering infected individuals as transmitters during the latency period, the mixed model SEIR results are based on the assumption that the latent individual contact rates are within 6-18. Thus, reducing the contact rate of latent individuals, interventions such as quarantine and isolation, could effectively reduce the potential peak number of COVID-19 infections and delay the peak infection time. Other studies using the SEIRS method have also revealed that the SEIRS model is effective in predicting COVID-19 in seeing the size and peak of the epidemic [21].

\section{Quarantine program in Singapore}

In this study, quarantine was divided into a control group (baseline) and an intervention group. In the baseline group, no intervention was carried out, while in the intervention group four intervention scenarios were carried out, namely: quarantine group, quarantine plus (school), quarantine plus (workplace distancing), and combination intervention. In the quarantine group, infected individuals are isolated and their family members are quarantined. Quarantine of infected individuals occurs 1 day after the onset of symptoms in a health-care facility and is fully equipped to handle full quarantine measures (i.e., negative pressure isolation rooms and full personal protective equipment used by staff) so that individuals cannot transmit SARS-CoV-2 to patients' other hospitalizations. At full hospitalization capacity, the remaining individuals are isolated at home after receiving treatment. Family members of the infected individual are quarantined at home for 14 days because transmission in the family is possible because of an isolated and infected individual.

In the quarantine plus group, direct school closures were carried out for 2 weeks. Workplace distancing was carried out: $50 \%$ of the workforce were encouraged to work from home for 2 weeks. In the combination intervention group, a combined intervention was carried out where the school was immediately closed and the workplace distancing. Four intervention scenarios are proposed to be implemented following failure of local containment, following the policy options currently being assessed by the Singapore Ministry of Health, as standard interventions for respiratory virus control.

Each of the 1000 epidemic simulations has a set of parameters and is run for the baseline and four control strategies. The median simulation was determined as the cumulative mean number of cases at day 80. The same set of parameters is used for every 1000 simulation sets for each value of R0. When analyzing differences across infectivity scenarios, we compared the outputs of each simulation, using the same parameters, not the median of each grouping.

We calculated IQR as simulated $25^{\text {th }}$ and $75^{\text {th }}$ in terms of the number of cumulative cases at 80 days. Researchers used statistical software R (version 3.6.3) to plot charts and for all analyzes. We present intervention data for scenarios in which R0 is R0 15 (relatively mild outbreak), 2.0 (moderate outbreak), and $\mathrm{RO}=2.5$ (severe outbreak). The results of the study proved that in the intervention group there was a decrease in COVID cases compared to the baseline group. Compared to the baseline scenario, combined interventions are the most effective [9].

\section{Discussion}

The results of this systematic review found five quarantine programs carried out to prevent the spread of COVID-19. These programs include quarantine in the city of China, quarantine in Singapore, quarantine in France, and quarantine in Sweden. These four countries showed that the quarantine program had a good impact on the program to prevent the spread of COVID-19. Meanwhile, a policy that implemented by the country also influenced will reduce transmission of the virus [34].

\section{Quarantine program in China}

There were three studies related to quarantine carried out in China [6], [8], [21]. From these three studies, it was revealed that quarantine and isolation could effectively reduce the potential peak number of COVID-19 infections and delay the peak infection time [8]. Besides, the SEIRS model was effective in predicting the peak and size of the COVID-19 epidemic [6], [21].

The COVID-19 pandemic was spreading so fast and causing a large number of morbidities followed by the number of deaths, so it required fast and precise efforts to predict the number of victims affected and an appropriate transmission prevention program. Thus, the spread of COVID-19 can be inhibited and can reduce the addition of new cases. The WHO has provided guidelines for preventing the spread of this disease. Every country must carry out a program to prevent the transmission of COVID-19. The SEIRS model was used to predict the onset of an epidemic of a disease, and the results of the review revealed that this model can predict the peak and size of the epidemic.

\section{Quarantine program in Singapore}

From the results of this review, it revealed that by mitigating this COVID-19 and in combination with other interventions (combining quarantine, school closings, and workplace distancing) can prevent national outbreaks at the level of combined interventions (combining quarantine, school closings, and workplace distancing) can prevent national outbreaks at low infectivity rates and reduce the total number of infections 
significantly at higher infectivity rates [9]. From these findings, it shows that a combination of interventions can inhibit the spread of COVID-19.

The spread of COVID-19 can occur through coughing, sneezing, splashing saliva, when someone suffering from COVID-19 coughs or breathes, they release like droplets of liquid that also have the corona virus [5]. Therefore, this quarantine was needed to prevent the spread that was carried out in combination with other interventions. Mitigation will identify the potential hazards before this endemic COVID-19 event.

\section{Quarantine program in Sweden}

The quarantine program carried out in Sweden revealed that the initial evacuation of all passengers on a cruise ship, with conditions and situations with limited space and high mixing, it was recommended to immediately carry out quarantine after the COVID-19 outbreak was confirmed [25]. Consideration was carried out by quarantine based on the results of data analysis using the SEIRS model. This SEIRS model was widely used to predict the development of infectious diseases such as malaria [35].

\section{Quarantine programs in France}

From the results of the review, it was found that this laboratory-based quarantine program can reduce anxiety and reassure the population and decision makers [36]. The population examined in this incident were those who arrived from abroad and entered France. With this laboratory-based quarantine procedure, they were calmer and sure whether they were infected (positive COVID-19) or not infected. This was important for both the stolen group and the government to determine the policy to be taken next.

The COVID-19 examination consists of several stages starting from rapid testing or using PCR. This examination can confirm the presence of infection by COVID-19 so that if someone is clearly infected then automatic quarantine can be carried out properly so that it will not endanger him and or others. Likewise, for the government, the results of laboratory-based examinations will make it easier to issue appropriate policies.

\section{Strengths and weaknesses}

The strengths of this systematic review were that it revealed the quarantine intervention program to prevent or reduce the spread of COVID-19 which was a new case and there was no way to prevent it from spreading. In the table analysis, the program interventions and their revealed implementation were in detail, thus providing a clear picture for program users. While, the shortcomings of this systematic review were still limited to countries affected by COVID-19 which were very broad so that they have not disclosed the prevention programs of the spread of COVID-19 in other countries.

\section{Conclusion}

Based on the results of the study, it can be concluded that the quarantine program has proven to be beneficial in preventing or reducing the spread of COVID-19. Suggestion: The government can use these programs to prevent and reduce the spread of disease caused by COVID-19.

\section{References}

1. Sorooshian S. Quarantine decision due to Coronavirus pandemic. Electron J Gen Med. 2020;17(4):em206.

2. Telehealth for global emergencies: Implications for Coronavirus disease 2019 (COVID-19). J Telemed Telecare. 2020;26(5):309-13. https://doi.org/10.1177/1357633X20916567 PMid:32196391

3. Chan JF, Yuan S, Kok KH, To KK, Chu H, Yang J, et al. A familial cluster of pneumonia associated with the 2019 novel Coronavirus indicating person-to-person transmission: A study of a family cluster. Lancet. 2020;395(10223):514-23. https://doi. org/10.1016/S0140-6736(20)30154-9

PMid:31986261

4. Chen N, Zhou M, Dong X, Qu J, Gong F, Han Y, et al. Epidemiological and clinical characteristics of 99 cases of 2019 novel Coronavirus pneumonia in Wuhan, China: A descriptive study. Lancet. 2020;395(10223):507-13. https://doi.org/10.1016/ S0140-6736(20)30211-7

PMid:32007143

5. World Health Organization. Coronavirus Disease 2019 (COVID-19): Situation Report No. 72. Geneva: World Health Organization; 2020.

6. Pan A, Liu L, Wang C, Guo H, Hao X, Wang Q, et al Association of public health interventions with the epidemiology of the COVID-19 outbreak in Wuhan, China. JAMA. 2020;323(19):1915-23. https://doi.org/10.1001/jama.2020.6130 PMid:32275295

7. Wang C, Pan R, Wan X, Tan Y, Xu L, Ho CS, et al. Immediate psychological responses and associated factors during the initial stage of the 2019 Coronavirus disease (COVID-19) epidemic among the general population in China. Int J Environ Res Public Health. 2020;17(5):1729. https://doi.org/10.3390/ ijerph17051729

PMid:32155789

8. Hou C, Chen J, Zhou Y, Hua L, Yuan J, He S, et al. The effectiveness of quarantine of Wuhan city against the Coronavirus disease 2019 (COVID-19): A well-mixed SEIR model analysis. J Med Virol. 2020;92(7):841-8. https://doi. org/10.1002/jmv.25827

PMid:32243599

9. Koo JR, CookAR, Park M, Sun Y, Sun H, Lim JT, et al. Interventions to mitigate early spread of SARS-CoV-2 in Singapore: A modelling study. Lancet Infect Dis. 2020;20(6):678-88. https:// 
doi.org/10.1016/S1473-3099(20)30162-6

PMid:32213332

10. Wang C, Horby PW, Hayden FG, Gao GF. A novel coronavirus outbreak of globalhealthconcern. Lancet.2020;395(10223):470-3. https://doi.org/10.1016/S0140-6736(20)30185-9 PMid:31986257

11. Deng L, Li C, Zeng Q, Liu X, Li X, Zhang H, et al. Arbidol combined with $L P V / r$ versus $L P V / r$ alone against Coronavirus disease 2019: A retrospective cohort study. J Infect. 2020;81(1):e1-5. https://doi.org/10.1016/j.jinf.2020.03.002

PMid:32171872

12. Chen H, Guo J, Wang C, Luo F, Yu X, Zhang W, et al. Clinical characteristics and intrauterine vertical transmission potential of COVID-19 infection in nine pregnant women: A retrospective review of medical records. Lancet. 2020;395(10226):809-15. https://doi.org/10.1016/S0140-6736(20)30360-3

PMid:32151335

13. China National Health Commission. Update on the Novel Coronavirus Pneumonia Outbreak;2020. Available from: https:// www.who.int/docs/default-source/coronaviruse/situationreports/20200121-sitrep-1-2019-ncov.pdf. [Last accessed on 2021 May 23].

14. US Centers for Disease Control and Prevention. First TravelRelated Case of 2019 Novel Coronavirus Detected in United States; 2019. Available from: https://www.cdc.gov/media/ releases/2020/p0121-novel-coronavirus-travel-case.html. [Last accessed on 2021 May 23].

15. World Health Organization. Novel Coronavirus-Republic of Korea (Ex-China). Geneva: World Health Organization; 2020. Available from: https://reliefweb.int/report/republic-korea/novelcoronavirus-republic-korea-ex-china-disease-outbreak-news21-january. [Last accessed on 2021 May 23].

16. Cohen J, Kupferschmidt K. Countries test tactics in 'war' against COVID-19. Science. 2020;367(6484):1287-8. https://doi. org/10.1126/science.367.6484.1287 PMid:32193299

17. Bogoch II, Watts A, Thomas-Bachli A, Huber C, Kraemer MU, Khan K. Pneumonia of unknown aetiology in Wuhan, China: Potential for international spread via commercial air travel. J Travel Med. 2020;27(2):taaa008. https://doi.org/10.1093/jtm/taaa008 PMid:31943059

18. Huang C, Wang Y, Li X, Ren L, Zhao J, Hu Y, et al. Clinical features of patients infected with 2019 novel Coronavirus in Wuhan, China. Lancet 2020;395(10223):497-506. https://doi. org/10.1016/S0140-6736(20)30183-5

\section{PMid:31986264}

19. Nishiura H, Jung SM, Linton NM, Kinoshita R, Yang Y, Hayashi K, et al. The extent of transmission of novel Coronavirus in Wuhan, China, 2020. J Clin Med. 2020;9(2):330. https://doi.org/10.3390/ jcm9020330

PMid:31991628

20. Thompson RN. Novel Coronavirus outbreak in Wuhan, China, 2020: Intense surveillance is vital for preventing sustained transmission in new locations. J Clin Med. 2020;9(2):498. https://doi.org/10.3390/jcm9020498

PMid:32054124

21. Yang Z, Zeng Z, Wang K, Wong SS, Liang W, Zanin M, et al. Modified SEIR and AI prediction of the epidemics trend of COVID-19 in China under public health interventions. J Thorac Dis. 2020;12(3):165-74. https://doi.org/10.21037/jtd.2020.02.64 PMid:32274081

22. World Health Organization. Update 95-SARS: Chronology of a Serial Killer. Geneva: World Health Organization; 2003. Available from: https://www.who.int/csr/don/2003 07 04/en. [Last accessed on 2021 May 23]
23. Cohen J, Normile D. New SARS-like virus in China triggers alarm. Science. 2020;367(6475):234-5. https://doi.org/10.1126/ science.367.6475.234

PMid:31949058

24. ParryJ. SARS virus identified, but the disease is still spreading. BMJ. 2003;326(7395):897. https://doi.org/10.1136/ bmj.326.7395.897

PMid:12714455

25. Rocklöv J, Sjödin H, Wilder-Smith A. COVID-19 outbreak on the Diamond Princess cruise ship: Estimating the epidemic potential and effectiveness of public health countermeasures. J Travel Med. 2020;27(3):taaa030. https://doi.org/10.1093/jtm/taaa030 PMid:32109273

26. Holshue ML, DeBolt C, Lindquist S, Lofy $\mathrm{KH}$, Wiesman J, Bruce $\mathrm{H}$, et al. First case of 2019 novel Coronavirus in the United States. N Engl J Med. 2020;382(10):929-36. https://doi. org/10.1056/NEJMoa2001191 PMid:32004427

27. Pan F, Ye T, Sun P, Gui S, Liang B, Li L, et al. Time course of lung changes at chest $\mathrm{CT}$ during recovery from Coronavirus disease 2019 (COVID-19). Radiology. 2020;295(3):715-21. https://doi.org/10.1148/radiol.2020200370 PMid:32053470

28. Li Q, Guan X, Wu P, Wang X, Zhou L, Tong $\mathrm{Y}$, et al. Early transmission dynamics in Wuhan, China, of novel Coronavirusinfected pneumonia. N Engl J Med. 2020;382(13):1199-207. https://doi.org/10.1056/NEJMoa2001316 PMid:31995857

29. Sun N, Wei L, Shi S, Jiao D, Song R, Ma L, et al. A qualitative study on the psychological experience of caregivers of COVID-19 patients. Am J Infect Control. 2020;48(6):592-8. https://doi.org/10.1016/j.ajic.2020.03.018 PMid:32334904

30. Ho CY, Yan B, Symons RC, Hardy TG. Paracentral acute middle maculopathy in a case of high-flow direct carotid cavernous fistula. Retin Cases Brief Rep. 2020. https://doi.org/10.1097/ ICB.0000000000000996 PMid:32205713

31. Wang G, Zhang $Y$, Zhao J, Zhang J, Jiang F. Mitigate the effects of home confinement on children during the COVID19 outbreak. Lancet. 2020;395(10228):945-7. https://doi. org/10.1016/S0140-6736(20)30547-X PMid:32145186

32. Cohen J. Scientists are Racing to Model the Next Moves of a Coronavirus that's Still Hard to Predict; Science. AAAS; 2020.

33. Moher D, Liberati A, Tetzlaff J, Altman DG, PRISMA Group. Preferred reporting items for systematic reviews and meta-analyses: The PRISMA statement. Ann Intern Med. 2009:151(4):264-9, W64. https://doi. org/10.7326/0003-4819-151-4-200908180-00135 PMid:19622511

34. Telles CR, RoyA,Ajmal MR, Mustafa SK,Ahmad MA, de la Serna JM, et al. The impact of COVID-19 management policies tailored to Airborne SARS-CoV-2 transmission: Policy analysis. JMIR Public Health Surveill. 2021;7(4):e20699. https://doi.org/10.2196/20699 PMid:33729168

35. Resmawan R, Nurwan N. Construction of basic reproductive numbers in the SEIRS-SEI epidemic model of malaria spread by vaccination and treatment. J Matematika Integratif. 2017;13(2):105-14.

36. Lagier JC, Colson P, Tissot Dupont H, Salomon J, Doudier B Aubry C, et al. Testing the repatriated for SARS-Cov2: Should laboratory-based quarantine replace traditional quarantine? Travel Med Infect Dis. 2020;34:101624. https://doi.org/10.1016/j. tmaid.2020.101624

PMid:32179125 